\title{
Analysis of Lower Tropospheric Lapse Rate Trend over Port Harcourt Coastal City, Nigeria
}

\author{
Vincent E. Weli, David O. Edokpa \\ Department of Geography and Environmental Management, University of Port Harcourt, Port Harcourt, Nigeria \\ Email: welivinezi@yahoo.com, onojiede@gmail.com
}

How to cite this paper: Weli, V.E. and Edokpa, D.O. (2018) Analysis of Lower Tropospheric Lapse Rate Trend over Port Harcourt Coastal City, Nigeria. Atmospheric and Climate Sciences, 8, 134-142. https://doi.org/10.4236/acs.2018.82010

Received: October 26, 2017

Accepted: February 20, 2018

Published: February 23, 2018

Copyright $\odot 2018$ by authors and Scientific Research Publishing Inc. This work is licensed under the Creative Commons Attribution International License (CC BY 4.0).

http://creativecommons.org/licenses/by/4.0/

\section{(c) (i) Open Access}

\begin{abstract}
Understanding the spatial distribution of temperature, especially the relationship between temperature and altitude, is essential for understanding both climatological and hydrological processes and their variabilities. This is because those processes are sensitive to air temperature, especially in sub humid tropical regions, where air temperature influences the movements of pollutants and controls exchanges of energy and water fluxes between land and atmosphere particularly within the lower troposphere. This study examined the trend of lower tropospheric lapse rate in the coastal area of Port Harcourt, Nigeria. Six years' data (2010-2015) for temperature between 1000 mbar and 850 mbar pressure levels was retrieved from era-interim re-analysis platform for the analysis. The data was acquired at 6-hourly synoptic hours: $0000 \mathrm{H}$, $0600 \mathrm{H}, 1200 \mathrm{H}$ and $1800 \mathrm{H}$ at $0.125^{\circ}$ grid resolution. Findings from the computed environmental lapse rate (ELR) show that conditional instability with an annual lapse rate of $5.5^{\circ} \mathrm{C} / \mathrm{km}$ persists at the area from January to December. It was revealed that the months of December and January constituted the highest ELR trends of $6.5^{\circ} \mathrm{C} / \mathrm{km}$ and $5.9^{\circ} \mathrm{C} / \mathrm{km}$ respectively. This indicates that the month of December assumes a normal tropospheric lapse rate trend. The average range of lapse rate trend in the area which is close to the moist adiabatic lapse rate (MALR) of $5.0^{\circ} \mathrm{C} / \mathrm{km}$ than the dry adiabatic lapse rate (DALR) shows that the study atmospheric environment is rich in water vapour. The 6-hourly synoptic analysis of the ELR pattern shows that lapse rate range between $1^{\circ} \mathrm{C} / \mathrm{km}-6.4^{\circ} \mathrm{C} / \mathrm{km}$ and $6.5^{\circ} \mathrm{C} / \mathrm{km}-10^{\circ} \mathrm{C} / \mathrm{km}$ dominates throughout the year at $0000-0600 \mathrm{Hrs}$ and $1200-1800 \mathrm{Hrs}$ respectively. This demonstrates a higher and lower lapse rate trend during the day and night periods respectively. Relating study findings to the potential of air to disperse emissions in the area suggests that air emissions will be conveyed through far and near distances across the boundary layers due to the moderate dispersive potential of air regarding the closeness of the average ELR to the MALR. Policies that will ensure that pollutants are dispersed aloft especially emission stacks
\end{abstract}


above $50 \mathrm{~m}$ is advocated in the city of Port Harcourt.

\section{Keywords}

Lapse Rates, Lower Troposphere, Port Harcourt, Emissions

\section{Introduction}

The weather and climate form within the lower atmosphere is determined by the state of vertical motion [1]. The term "lapse rate" highlights this state of the atmosphere and how it relates to other atmospheric variables. It has been noted by [2] that one of the vital enhancing forces of atmospheric stability is its association of temperature with height. The extent of variation in surface temperature with altitude is referred to as temperature lapse rate. Several studies had revealed that temperature drops with heights and that temperature lapse rate is one of the regulating factors controlling the structure of any planetary atmosphere [3] [4]. An understanding of lapse rates is crucial in micro scale air pollution dispersion investigation, as well as urban noise pollution modeling, forest fire-fighting and certain aviation applications. Lapse rate which strongly depends on the deviation of altitudinal temperature can either be positive or negative and regulates the nature of heat flux exchanges within the atmospheric boundary layer (ABL). Lapse rate is positive or negative when temperature decreases or increases with height. The ABL which begins from the surface layer up to $1-2 \mathrm{~km}$ creates the convective events that stimulate the circulations within the entire troposphere. The boundary layer spreads past $1 \mathrm{~km}$ during the day and contracts to below 400 $\mathrm{m}$ during periods of the down [5]. This change of height relative to time of day is based on the degree of mixing subject to the lapse rate pattern at any given time [6] [7] [8] [9] [4]. This has serious implications for pollutants mixing.

Pollution in the atmospheric medium travels the farthest and industrial emissions are one of the most important sources of air pollution in Port Harcourt. The implications of the location and pattern of industries for pollution are many. The dominant air mass over Port Harcourt is the South West Trade Wind. Detailed wind flow characteristics over the city include periodic doses of emission from the major industrial locations around the city [10] [11]. The incidence of land breeze, as well as, the Harmattan factor actually transfers emissions into the city [12].

There are two types of lapse rate: environmental or normal lapse rate (ELR) and adiabatic lapse rate. The former is the nature of ambient temperature pattern with increase in height while the latter is relating the notion of an ideal gas situation as a base to compare with the normal lapse rate. It was specified [13] that the ELR is the actual change of temperature reduction with height for a static atmosphere at a given period and place within the lower atmosphere. The dry adiabatic and moist adiabatic lapse rates (DALR and MALR) are the types of 
adiabatic lapse rate for an ideal gas situation at any given atmospheric condition and the typical convectional rates are $9.8^{\circ} \mathrm{C} / \mathrm{km} \mathrm{[14]} \mathrm{and} 5.0^{\circ} \mathrm{C} / \mathrm{km}[15]$ respectively. The universal atmospheric standard for a normal lapse rate is $6.5^{\circ} \mathrm{C} / \mathrm{km}$ [8]. This lapse rate value varies from place to place on the earth surface depending on the air characteristics of any environment. It was also indicated [8] that the ELR is wholly applicable to maximum temperature as it unsatisfactorily overestimates minimum temperature and mean temperature lapse rates. The lapse rate pattern for any locality makes the local atmospheric stability either unstable, neutral or stable (inversion). The basis for this stability condition is the comparison of the environmental lapse rate to the adiabatic lapse rates. It is very important to note that the effectiveness of pollutants dispersion and concentrations at any given time depends on the category of lapse rate prevalent at any place or location. When the ELR is greater than both the MALR and DALR, unstable atmospheric condition exists which enhances pollutants dispersion. However, when the ELR is lesser than both MALR and DALR, stable atmospheric condition exists which ensures the stagnation of pollutants dispersion. When the ELR is greater than the MALR but lesser than the DALR, conditional instability exists. In this case, the atmosphere is stable and unstable during unsaturated and saturated periods respectively.

\section{Study Area}

Port Harcourt is located in the Niger delta part of Nigeria with boundaries between Latitudes $4^{\circ} 45^{\prime} \mathrm{E}-4^{\circ} 0^{\prime} \mathrm{N}$ and Longitudes $6^{\circ} 55^{\prime} \mathrm{E}-7^{\circ} 56^{\prime} \mathrm{E}$ (Figure 1). The area is located around the coastal region dominated by low setting coastal plains of sedimentary formations [16]. The area has a tropical humid monsoon climate influenced by its nearness to the Atlantic Ocean. This influence from the Ocean exposes the area to the effects of land and sea breeze. Two principal air masses controls rainfall duration across the area: moist and warm northward moving tropical maritime air from the Ocean and the dry and warm tropical continental air from across the Saharan desert. The rainfall periods last from March to November while the dry periods last from December to February. As a result of the robust presence of the warm moist south-west wind, the area receives an average rainfall amount of roughly $2300 \mathrm{~mm}$ [17]. The bi-modal rainfall regime observed in the areas attains its peaks in July and September [18]. The average high and low temperature values are $32^{\circ} \mathrm{C}$ and $26^{\circ} \mathrm{C}$ observed in January and July respectively [19]. The average relative humidity for the area ranges from $66 \%-96 \%$ throughout the year [20] with high and low values during the wet and dry seasons respectively. Due to the massive water vapour in the atmosphere as a result of nearby water bodies, cloud cover pattern in the area is constantly being enhanced with monthly average of over 5 oktas. This impact on the mean daily sunshine duration where less than 4 hours is observed in July and about 4 - 6 hours observed in January and December. Average monthly wind speed ranges from $0-4 \mathrm{~m} / \mathrm{s}$ with high and low peaks during the day and periods respectively. 


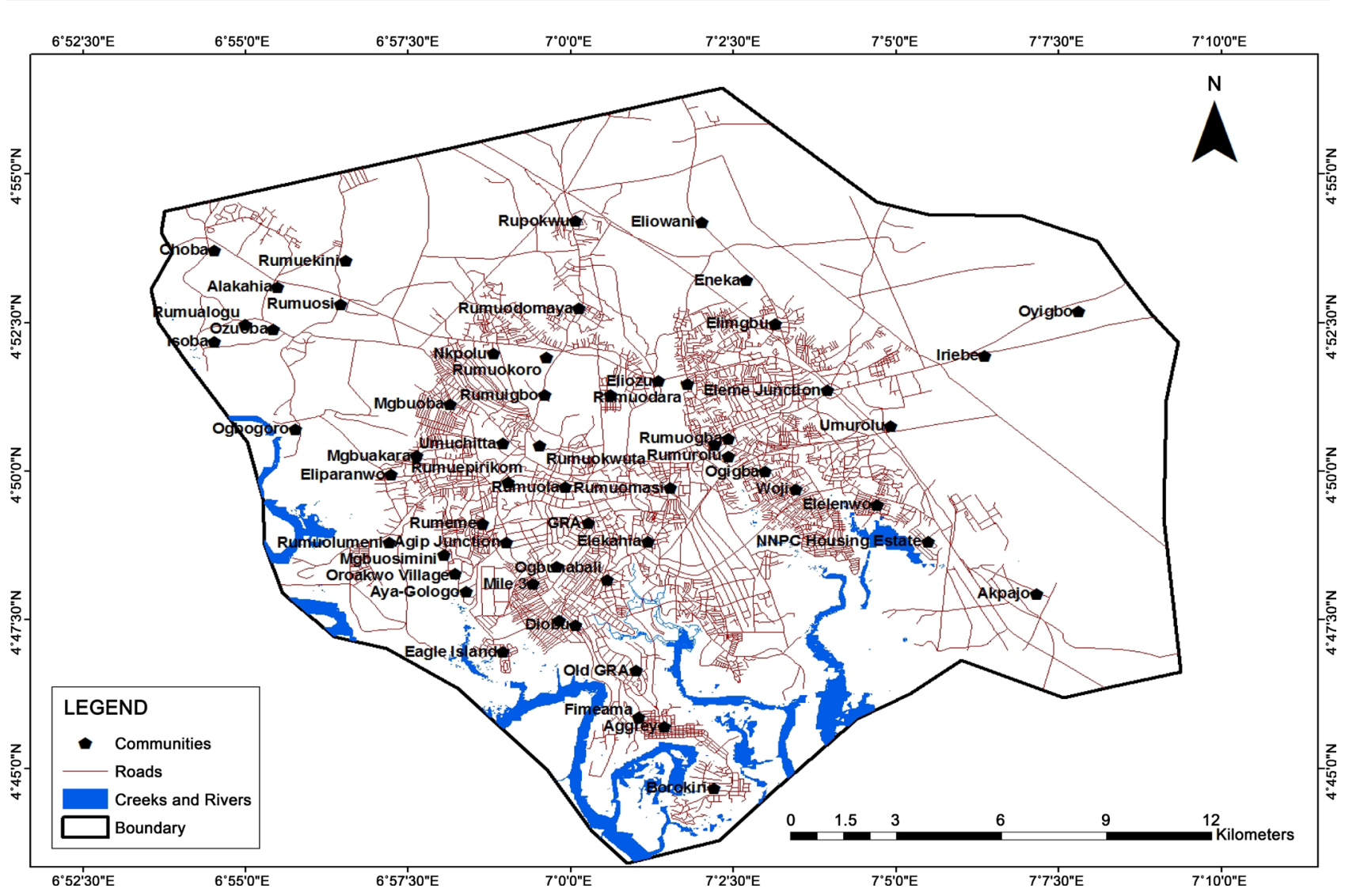

Figure 1. Map showing study area.

\section{Data and Methodology}

The data for this study was retrieved from the updated Era-Interim Re-analysis data for six years (2010-2015). The Era-Interim platform is the latest and refined widespread atmospheric reanalysis data and has been found very useful in the investigation of the atmospheric circulation system of West African. The use of the reanalysis data has surpassed projections and articulates progressive assessments about the accomplishments in the analysis of weather data realised within the last decade. The data was retrieved at 0.125 degree resolution for 6-hourly interval at 0000, 0600, 1200 and 1800 synoptic hours. Upper air temperature values at pressure level $850 \mathrm{mbar}$ and $1000 \mathrm{mbar}$ for an approximate surface level was obtained. Range of lapse rate values from $1^{\circ} \mathrm{C} / \mathrm{km}-6.4^{\circ} \mathrm{C} / \mathrm{km}$ and $6.5^{\circ} \mathrm{C} / \mathrm{km}-10^{\circ} \mathrm{C} / \mathrm{km}$ was used to categorise the closeness of the evaluated ELR trend to either the MALR of DALR. This was to determine the dry or moist nature of air in the study area.

The environmental lapse rate for the area was determined using the following equation [21]

$$
T_{850 \mathrm{mbar}}=T_{1000 \mathrm{mbar}}-\Gamma \cdot \partial \mathrm{z}
$$

where:

$$
\begin{aligned}
& \left.T_{850 \mathrm{mbar}}=\text { air temperature at reference height (approximately } 1400 \mathrm{~m}\right) \\
& \left.T_{1000 \mathrm{mabr}}=\text { air temperature at surface level (approximately } 10 \mathrm{~m}\right)
\end{aligned}
$$


$\Gamma=$ environmental lapse rate

$\partial z=$ the difference in elevation between the two heights.

The relationship between the environmental lapse rate (ELR) and the air parcel lapse rates (dry and moist adiabatic lapse rates (DALR \& MALR) was used in this study to determine the major domain of the atmospheric stability conditions as it relate to the lapse rate pattern of the study area. The following criteria were adopted for stability classification.

- $\mathrm{ELR}=6.5^{\circ} \mathrm{C} / \mathrm{km}$

- $\operatorname{DALR}=9.8^{\circ} \mathrm{C} / \mathrm{km}$

- $\operatorname{SALR}=5.0^{\circ} \mathrm{C} / \mathrm{km}$

When:

- $\quad \mathrm{ELR}<\mathrm{SALR}<\mathrm{DALR}=$ Stable Atmospheric Conditions

- SALR $<$ DALR $<$ ELR = Unstable Atmospheric Conditions

- SALR $<$ ELR $<$ DALR = Conditional Instability

- $\quad \mathrm{ELR}=\mathrm{DALR}=$ Neutral Atmospheric Conditions (Unsaturated Air)

- $\quad E L R=$ SALR $=$ Neutral Atmospheric Conditions (Saturated Air)

MATLAB software was utilised in analysing the mathematical equations and the frequency of lapse rate distribution.

\section{Results and Discussion}

Table 1 shows the mean daily ELR lapse rate for Port Harcourt with the corresponding prevalent atmospheric stability conditions. Since the analysed average ELR for the whole months is greater than the MALR $\left(5.0^{\circ} \mathrm{C} / \mathrm{km}\right)$ but lesser than the $\operatorname{DALR}\left(9.8^{\circ} \mathrm{C} / \mathrm{km}\right)$, conditional instability dominates in the study area.

Table 1. Average daily lapse rate trend for the various months.

\begin{tabular}{cccl}
\hline S/No & Month & $\begin{array}{r}\text { Analysed Lapse Rate } \\
\left({ }^{\circ} \mathrm{C} / \mathrm{km}\right)\end{array}$ & $\begin{array}{c}\text { Corresponding Atmospheric } \\
\text { Stability Profile }\end{array}$ \\
\hline 1 & January & -5.9 & Conditional Instability \\
2 & February & -5.4 & Conditional Instability \\
3 & March & -5.5 & Conditional Instability \\
4 & April & -5.6 & Conditional Instability \\
5 & May & -5.5 & Conditional Instability \\
6 & June & -5.2 & Conditional Instability \\
7 & July & -5.5 & Conditional Instability \\
8 & August & -5.5 & Conditional Instability \\
9 & September & -5.3 & Conditional Instability \\
10 & October & -5.3 & Conditional Instability \\
11 & November & -5.4 & Conditional Instability \\
12 & December & -6.5 & Conditional Instability \\
& Mean & 5.5 & Conditional Instability \\
\hline
\end{tabular}


Conditional instability depends on the moisture distribution in the atmosphere. Under this condition, an air parcel at the ELR is unstable to both upward and downward displacement when saturated and stable to lesser vertical displacement when unsaturated.

Analysed results have shown that the average daily lapse rate for the lower troposphere across the area is positive throughout the months. December and January constituted the highest daily lapse rate for the periods under study i.e. $-6.5^{\circ} \mathrm{C} / \mathrm{km}$ and $5.9^{\circ} \mathrm{C} / \mathrm{km}$ while June, September and October had the least values i.e. $-5.2^{\circ} \mathrm{C} / \mathrm{km}, 5.3^{\circ} \mathrm{C} / \mathrm{km}$ and $5.3^{\circ} \mathrm{C} / \mathrm{km}$ respectively. The annual average lapse rate value for the area is $5.5^{\circ} \mathrm{C} / \mathrm{km}$ (Table 1 ). From result analysis, the average values for the ELR which tends towards the MALR value of $5.0^{\circ} \mathrm{C} / \mathrm{km}$ indicates that atmospheric air in the study area is moist than dry. This is largely due to continentality effects as the atmosphere inland is being moderated by the air from the Ocean. It was admitted [22] that mean temperature profile in the tropics approximately follow a moist adiabat. It has been acknowledged [23] that the tropical region is principally characterised by more or less uniform decrease in temperature with height within the lower tropospheric layer. It was also argued [24] that surface warming causes an upward shift and decrease in area of high clouds, and a sharp decline in midlevel clouds, but no systematic trend in low cloud cover.

Figure 2 and Figure 3 show the frequency distribution of the ELR for the various synoptic hours. Analysis shows that normal lapse rate occurrence for range $1^{\circ} \mathrm{C} / \mathrm{km}-6.4^{\circ} \mathrm{C} / \mathrm{km}$ was high throughout the year during the period's 0000 - 0600 hours. At $1200-1800$ hours, lapse rate range $6.5^{\circ} \mathrm{C} / \mathrm{km}-10^{\circ} \mathrm{C} / \mathrm{km}$ was dominant throughout the year with peaks in January, April and December.

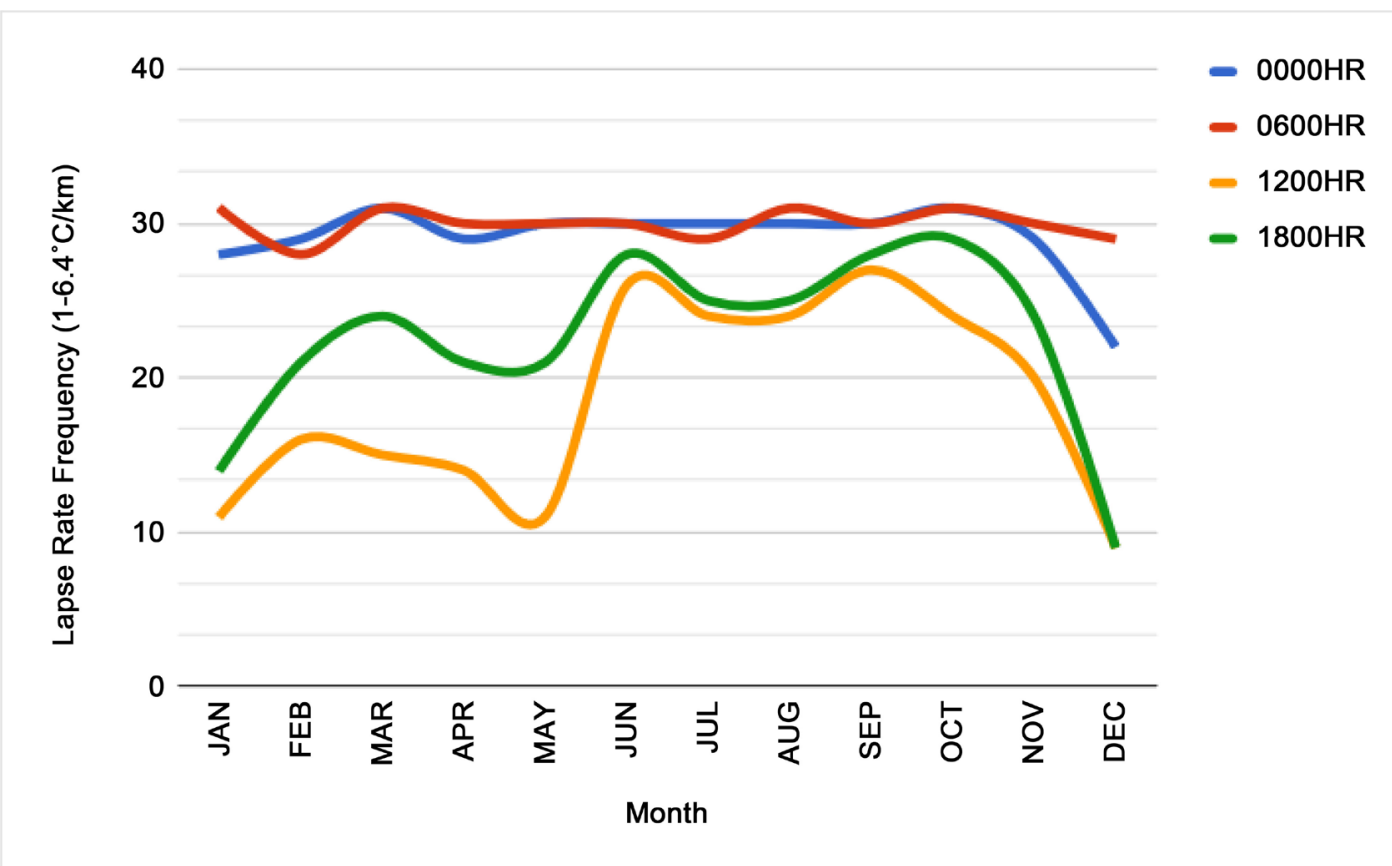

Figure 2. Lapse rate frequency $\left(1^{\circ} \mathrm{C} / \mathrm{km}-6.4^{\circ} \mathrm{C} / \mathrm{km}\right)$ for study area. 


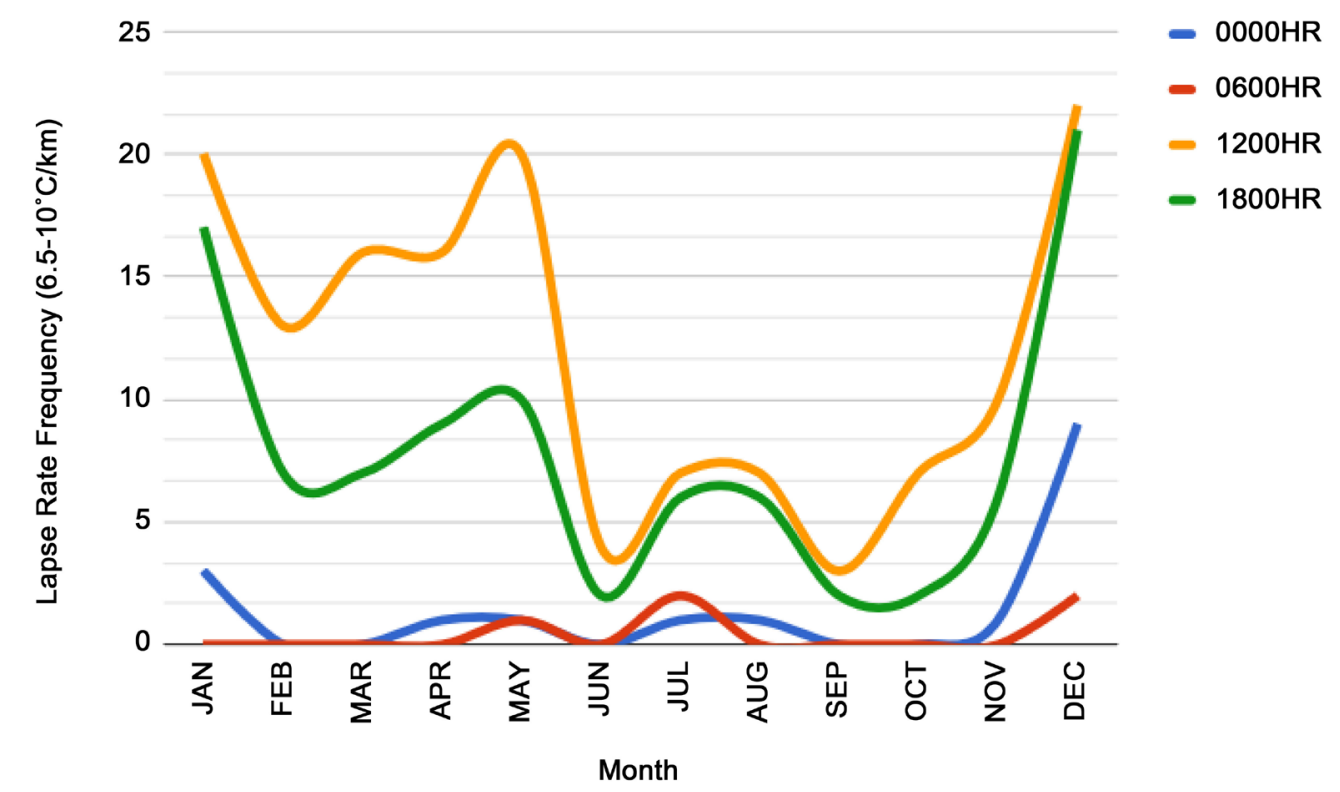

Figure 3. Lapse Rate Frequency $\left(6.5^{\circ} \mathrm{C} / \mathrm{km}-10^{\circ} \mathrm{C} / \mathrm{km}\right)$ for Study Area.

However, the low peaks observed between June and October indicates wet periods when relative humidity is highest in the area. During these periods the air parcel ELR tends towards the MALR. It has been cited by [25] and [4] has cited that lapse rate is typically steeper during day period than at night time as well as during hotter season than in colder periods.

Factors which enhances the moderate lapse rate pattern of the study environment includes: the dominant moist tropical maritime air mass from across the Ocean which engulfs the entire study area and moderates high temperature regime over land; the high cloud cover pattern which is averagely $60 \%$ and $90 \%$ during the dry and wet season respectively, the less duration of solar radiation as well as the moist soil surface condition which accumulates surface heat flux and releases sensible heat flux at a slower pace. These findings corroborate the works of [4] [26] and [27] which concludes that the evaluation of estimated lapse rate shows that the estimates are reasonable and useful for temperature-related analyses and modelling studies and also argued that The lapse rates maintain a consistently positive correlation with temperature in all seasons but exhibit a negative relationship with relative humidity in all seasons.

\section{Conclusion}

The lapse rate conditions at any location play a key role in the vertical movement of energy and momentum fluxes in the troposphere and how air pollutants are transported and dispersed in the atmosphere. From the assessed environmental or normal lapse rate condition of the study area, it can be observed that conditional instability persists throughout the year. The term conditional stability which is based on the moisture situation of the atmosphere determine the 
unstable and stable pattern of an air parcel during saturated and unsaturated conditions respectively. The study area exhibited a moderate lapse rate condition that is close to the moist adiabatic lapse rate (MALR). This atmospheric condition indicates the area's closeness to the dominant source of the moist and warm tropical maritime air mass which modifies the weather condition of the area. The moderate lapse rate pattern of the area suggests that air contaminants concentrations under the moderate wind speed condition prevalent in the area will be dispersed to both near and far receptors downwind of the source.

\section{References}

[1] Dutt, A. and Limaye, S.S. (2015) Adiabatic Lapse Rate and Static Stability in the Venus Atmosphere. Venus Lab and Technology Workshop, Bombay, India.

[2] Fritz, B.K. (2003) Measurement and Analysis of Atmospheric Stability in Two Texas Regions. A presentation at the ASAE/NAN Technical Session, AA03-00X. St. Joseph, Michigan.

[3] Mokhov, I.I. and Akperov, M.G. (2006) Tropospheric Lapse Rate and Its Relations to Surface Temperature from Reanalysis Data. Atmospheric and Oceanic Physics, 42, 430-438. https://doi.org/10.1134/S0001433806040037

[4] Li, X., Wang, L., Chen, D., Yang, K., Xue, B. and Sun, L. (2013) Near-Surface Air Temperature Lapse Rates in the Mainland China during 1962-2011. Journal of Geophysical Research: Atmospheres, 118, 7505-7515. https://doi.org/10.1002/jgrd.50553

[5] Arya, P. (1998) Introduction to Micrometeorology. 2nd Edition. Academic Press, San Diego.

[6] Stull, R.B. (2001) An Introduction to Boundary Layer Meteorology. Kluwer Academic Publishers.

[7] Salomons, E.M. (2001) Computational Atmospheric Acoustics. Kluwer Academic Publishers. https://doi.org/10.1007/978-94-010-0660-6

[8] Blandford, T.R., Humes, K.S., Harshburger, B.J., Moore, B.C., Walden, V.P. and Ye, H.C. (2008) Seasonal and Synoptic Variations in Near-Surface Air Temperature Lapse Rates in a Mountainous Basin. Journal of Applied Meteorology and Climatology, 47, 249-261. https://doi.org/10.1175/2007JAMC1565.1

[9] Ayoade, J.O. (2004) Introduction to Climatology for the Tropics. 2nd Edition, Spectrum Books, Ibadan.

[10] Oliver, J.E. (2005) The Encyclopaedia of World Climatology. Dordrecht, Springer. https://doi.org/10.1007/1-4020-3266-8

[11] Weli, V.E. and Ayoade, J.O. (2014) Seasonal Urban-Rural Difference in Atmospheric Pollutant Concentration in Port Harcourt Region. International Journal of Environment and Pollution Research, 3, 48-61.

[12] Weli, V.E. (2014) Atmospheric Concentration of Particulate Pollutants and its Implications for Respiratory Health Hazard Management in Port Harcourt Metropolis, Nigeria. Civil and Environmental Research, 6, 11-17.

[13] Minder, J.R., Mote, P.W. and Lundquist, J.D. (2010) Surface Temperature Lapse Rates over Complex Terrain: Lessons from the Cascade Mountains. Journal of Geophysical Research, 115. https://doi.org/10.1029/2009JD013493

[14] Rosenberg, M. (2017) About Lapse Rate. 
https://www.thoughtco.com/about-lapse-rate-1435338

[15] Brandon, J. (2013) Atmospheric Thermodynamics 2 and Dynamics. https://www.recreationalflying.com/tutorials/meteorology/section1b.html

[16] Ojo, O. (1977) The Climates of West Africa. Heinemann, Ibadan.

[17] Dammo, M.N., Yadima, S.G. and Sangodoyin, A.Y. (2016) Observed Trend of Changes in Relative Humidity across North-East Nigeria (1981-2010). Civil and Environmental Research, 8, 73-76.

[18] Stull, R.B. (1988) An Introduction to Boundary Layer Meteorology. In: Atmospheric Sciences Library, Springer, Netherland. https://doi.org/10.1007/978-94-009-3027-8

[19] Muir, D.M. (2004) Air Pollution Control Technology. Department of Chemical and Process Engineering, University of Strathclyde Publications, Glasgow.

[20] Bailey, D.T. (2000) Meteorological Monitoring Guidance for Regulatory Modelling Applications. US Environmental Protection Agency. Office of Air and Radiation; Office of Air Quality Planning and Standards. https://www3.epa.gov/scram001/guidance/met/mmgrma.pdf

[21] Harlow, R.C., Burke, E.J., Scott, R.L., Shuttleworth, W.J., Brown, C.M. and Petti, J.R. (2004) Derivation of Temperature Lapse Rates in Semi-Arid South-Eastern Arizona. Hydrology and Earth System Sciences, 8, 1179-1185.

http://www7.nau.edu/mpcer/direnet/publications/publications_h/files/Harlow-2004 .pdf https://doi.org/10.5194/hess-8-1179-2004

[22] Folkins, I. (2006) Convective Damping of Buoyancy Anomalies and Its Effect on Lapse Rates in the Tropical Lower Atmosphere. Atmospheric Chemistry and Physics, 6, 1-12. https://doi.org/10.5194/acp-6-1-2006

[23] Olajire, M.A. and Mattew, O.J. (2013) Determination of the Vertical Variations in Temperature and Longwave Radiation within the Grey Earth's Troposphere Using Radiative Equilibrium Profile Model. International Journal of Physical Sciences, 8 , 1800-1806.

[24] Cronin, T.W. and Wing, A.A. (2017) Clouds, Circulation, and Climate Sensitivity in a Radiative-Convective Equilibrium Channel Model. Journal of Advances in Modeling Earth Systems, 9, 2883-2905. https://doi.org/10.1002/2017MS001111

[25] Roland, C. (2003) Spatial and Seasonal Variations of Air Temperature Lapse Rates in Alpine Regions. Journal of Climate, 16, 1032-1046. https://doi.org/10.1175/1520-0442(2003)016<1032:SASVOA $>2.0 . C O ; 2$

[26] Haiden, T., Whiteman, C.D., Hoch, S.W. and Lehner, M. (2011) A Mass Flux Model of Nocturnal Cold Air Intrusions into a Closed Basin. Journal of Applied Meteorology and Climatology, 50, 933-943. https://doi.org/10.1175/2010JAMC2540.1

[27] Li, Y., Zeng, Z., Zhao, L. and Piao, S. (2015) Spatial Patterns of Climatological Temperature Lapse Rate in Mainland China: A Multi-Time Scale Investigation. Journal of Geophysical Research: Atmospheres, 120, 2661-2675. https://doi.org/10.1002/2014JD022978 